\title{
OCULOMOTOR RESPONSE TO IMAGES IN PRIMARY SCHOOL CHILDREN WITH MILD INTELLECTUAL DISABILITY
}

Nikishina VB ${ }^{1}$, Prirodova OF${ }^{1}$, Petrash EA ${ }^{1 凶}$, Sevrukova IA²

${ }^{1}$ Pirogov Russian National Research Medical University, Moscow, Russia

2 Kursk State Medical University, Kursk, Russia

Oculomotor activity (eye movements) is an essential component of visual data acquisition, analysis and use. The aim of this study was to determine the characteristics of oculomotor response to static images in primary school children with mild intellectual disability (ID). Our sample included a total of 49 schoolers (23 children with mild ID and 26 typically developing children). Oculomotor activity was evaluated using a GP3 Gazepoint eye tracker. The participants were presented with 15 visual stimuli: 10 pictorial and 5 mixed (pictures + text) static color images. Children with mild ID generated significantly fewer fixations $(p=0.038)$ than typically developing children. So, learning materials containing both pictorial and textual images are ineffective because textual elements are completely ignored by children with mild ID. The total duration of gaze fixations was significantly longer $(p=0.029)$ in typically developing children than in children with mild ID. However, the average duration of a single gaze fixation was longer in children with mild ID. The identified features of oculomotor response can help to optimize the format of instructional materials for primary school children with mild ID

Keywords: oculomotor response, intellectual disability, gaze fixation, latency, fixation duration

Author contribution: Nikishina VB and Prirodova OF proposed the concept, interpreted and summarized the obtained data; Petrash EA performed qualitative and quantitative analysis of the obtained data; interpreted and summarized the results; Sevrukova IA conducted the study and performed data acquisition

Compliance with ethical standards: the study was approved by the Ethics Committee of Kursk Medical State University (Protocol № 9 dated December 10, 2019). Written informed consent was obtained from the children's parents or legal representatives.

$\triangle$ Correspondence should be addressed: Ekaterina A. Petrash

Ostrovityanova, 1, Moscow, 117997; petrash@mail.ru

Received: 21.01.2021 Accepted: 15.02.2021 Published online: 26.02.2021

DOI: $10.24075 /$ brsmu.2021.008

\section{ГЛАЗОДВИГАТЕЛЬНЫЕ РЕАКЦИИ ПРИ ВОСПРИЯТИИ ИЗОБРАЖЕНИЙ МЛАДШИМИ ШКОЛЬНИКАМИ С ЛЕГКОЙ СТЕПЕНЬЮ УМСТВЕННОЙ ОТСТАЛОСТИ}

В. Б. Никишина'

${ }^{1}$ Российский национальный исследовательский медицинский университет имени Н. И. Пирогова, Москва, Россия

${ }^{2}$ Курский государственный медицинский университет, Курск, Россия

Окуломоторная активность (глазодвигательные реакции) может быть необходимым компонентом психических процессов, связанных с получением, преобразованием и использованием зрительной информации. Целью работы было определить, каковы особенности глазодвигательных реакций при восприятии статичных изображений у младших школьников с легкой степенью умственной отсталости (УО). Объем выборки составил 49 человек: 23 человека с легкой степенью УО, 26 человек с нормативным типом психического развития. Оценку глазодвигательных реакций осуществляли с использованием программно-аппаратного комплекса GP3 Gazepoint. Стимульный материал представлял собой 15 статичных цветных изображений: картинки, содержащие только изображения (10 картинок); картинки, содержащие одновременно изображения и текст (5 картинок). В ходе исследования установлено, что число фиксаций у детей с легкой степенью УО значимо меньше (p=0,038) по сравнению с детьми с нормативным развитием. Одновременное размещение картинки и текстовой информации неэффективно, поскольку текстовая часть остается проигнорированной в полном объеме. Общая длительность фиксаций значимо выше ( $p=0,029)$ у детей с нормативным развитием по сравнению с детьми с легкой степенью УО. При этом средняя длительность единичной фиксации при УО выше. В практическом аспекте выявленные особенности глазодвигательных реакций у детей младшего школьного возраста с легкой степенью УО позволяют оптимизировать форму предъявления информации в процессе обучения.

Ключевые слова: глазодвигательные реакции, умственная отсталость, зрительные фиксации, латентное время фиксации, длительность фиксации

Вклад авторов: В. Б. Никишина - формирование концепции исследования, интерпретация и обобщение полученного эмпирического материала; О. Ф. Природова - формирование концепции исследования, интерпретация и обобщение полученного эмпирического материала; Е. А. Петраш количественная и качественная обработка полученного эмпирического материала, интерпретация и обобщение результатов исследования: И. А. Севрюкова - проведение исследования, сбор первичного эмпирического материала.

Соблюдение этических стандартов: исследование одобрено этическим комитетом Курского государственного медицинского университета (протокол № 9 от 10 декабря 2019 г.); родители или законные представители детей подписали добровольное информированное согласие на участие в исследовании.

$\triangle$ Для корреспонденции: Екатерина Анатольевна Петраш

ул. Островитянова, д. 1, г. Москва, 117997; petrash@mail.ru

Статья получена: 21.01.2021 Статья принята к печати: 15.02.2021 Опубликована онлайн: 26.02.2021

DOI: $10.24075 /$ vrgmu.2021.008

In 2019, 0 to 14-year-old Russians with first-time diagnosed intellectual disability (ID) amounted to $4.8 \%$ of all pediatric patients with mental disorders [1]. This number has been showing a positive curvilinear trend over the past 10 years.

At primary school, intentional learning is the leading type of activity, i.e. the main driver of a child's mental development. Visual perception forms the basis for intellectual activity. Children with perceptual differentiation deficiency cannot recognize an object from its parts and are unable to discriminate between similar-looking objects [2].

In order to address educational challenges faced by the teachers and parents of children with developmental disorders, visual perception should be viewed as a function involving the encoding and analysis of object features, their multisensory convergence, object identification, and the assessment of object importance [3]. 
Intellectual disability coded as F70 by ICD-10 is a type of developmental disorder. It is characterized by incomplete brain development, increased exhaustibility of mental activity, slow cortical activity, and compromised anatomy and physiology of the visual system underlying cognitive impairments, including sensory and perceptual dysfunction [4-10].

Visual perception is the sum of processes involved in creating a visual impression of the environment based on visual input [3].

In primary school children with cognitive disorders the generality of perception is compromised. Minor details and small objects go unnoticed; only salient features are perceived. The structural elements of an object are not recognized [4]. Children with ID have a narrow scope of visual perception. Typically developing primary school children are capable of simultaneously perceiving 8 to 12 small objects, whereas their peers with ID can only perceive 4-6 objects at a time [10].

Size constancy (perception of distant objects) is much worse in children with ID than in their typically developing peers [8].

Children with ID cannot establish connections or identify a relationship between animate or inanimate objects in a genre scene [5]. This may be due to slow mental activity and sequential picture processing. The analysis of eye trajectory during picture viewing reveals that the glance is often drawn to the same, probably more informative elements of the picture; other elements receive much less attention [7].

Summing up, the following aspects of visual perception are compromised in primary school children with mild ID: integrity, concreteness, fidelity, wholeness, constancy, scope, generality, selectivity, rate, and differentiation. Ocular motor responses (oculomotor activity) are the critical components of mental processes implicated in visual data acquisition, processing and use.

Dyslexic children are reported to generate more saccades when reading a static text than their typically developing peers. Dyslexic children also generate more than 3 saccades during gaze fixation tasks. This might be explained by the immaturity of their cortical structures responsible for saccadic inhibition [11].

A study of oculomotor reactions revealed that children with autism spectrum disorders were fast to fixate on human faces when presented with a socially relevant stimulus; after that, however, their attention slackened. The more pronounced was developmental delay, the more the participants fixated on the central elements of the presented picture. This might be explained by the low average saccade velocity in autistic children [12].

It is reported that lower $I Q$ is associated with slower response and less stable gaze fixations in children with various grades of ID [13].

A Russian study investigated oculomotor responses to texts in different age groups [14]. None of the studied eye movement parameters differed between older and younger dyslexic children. The immaturity of some brain structures might disrupt the formation of basic components of reading skills required for the successful analysis and understanding of written texts.

In contrast to typically developing children, their peers with mild ID need more time to read a text and make more fixations; fixation duration is longer, and the amplitude of saccades is reduced. This may be due to the impaired ability to perform phonemic analysis and understand letter/sound correspondences [15].

Preschoolers with mild ID make fewer and longer fixations when viewing static images due to limited visual perception [10] and its slow rate [4]. Incomplete or arrested development of brain structures can affect oculomotor response to images.
The aim of the study was to investigate the characteristics of oculomotor response to static images in primary school children with mild ID. The obtained data might be used to optimize the format of teaching materials for such children.

\section{METHODS}

\section{Study participants}

The study was carried out in 49 children aged 7-9 years who were in their first year at school (non-repeaters). The following inclusion criteria were applied: any sex; no visual impairment confirmed by an ophthalmologist. Exclusion criteria: chronic diseases.

The children were grouped by the type of mental development. The main group comprised 12 boys and 11 girls with mild ID (F70.0, MCl-10) and the average IQ of $63.57 \pm 3.24$, attending specialized schools for emotional and behavioral disorders (type VIII schools). The mean age of the children was $8.63 \pm 0.57$ years. The control group consisted of 26 typically developing children (11 boys and 15 girls; mean age: $8.12 \pm$ 0.81 years) pronounced healthy by the expert panel.

\section{Equipment: technical specifications, setup, calibration}

Oculomotor response studied using a GP3 Gazepoint eyetracking system (Gazepoint Research Inc.; Canada) that exploits a $60 \mathrm{~Hz}$ machine-vision camera to collect and analyze visual data. This eye tracker comes with Gazepoint Control and Gazepoint Analysis software for calibration, running experiments and data analysis.

\section{Both eyes were tracked simultaneously}

Technical specifications of the eye tracker: accuracy $0.5-1$ degree of visual angle; $60 \mathrm{~Hz}$ update rate; 5- and 9-point calibration; open-standard API; $25 \times 11 \mathrm{~cm}$ horizontal $\times$ vertical movement; $\pm 15 \mathrm{~cm}$ range of depth movement; USB-powered.

Computer requirements: modern processor (i5-i7); memory: 2 Gb; OS: Windows XP / Vista / 7/8, 32/64 bit; 15.6inch monitor; $1920 \times 1080$ screen resolution.

The following instructions were applied to create a project for each study participant: start Gazepoint Analysis $\rightarrow$ create a New project $\rightarrow$ select a folder to save the project $\rightarrow$ add a stimulus (a static image).

1. Areas of interest (AOI; images of individual objects simultaneously presented on the computer screen) were selected in the Analyze data mode. It is possible to select areas of interest on each presented image. The software collects statistics on the number of viewers who view the selected $\mathrm{AOI}$; the average time to the first view (latency); the average time spent on viewing the selected $\mathrm{AOI}$ (fixation duration); the average percentage of the total time spent on $\mathrm{AOI}$; the number of revisitors.

2. The Gazepoint Control window shows 4 types of settings: Calibrate, Gaze pointer, Select screen, and Switch Tracker Type.

The camera view in the middle of the screen helps to adjust the distance between the camera and the subject and right/left eye capture. Feedback information is provided in the bottom status bar, which shows frame time $(16.6 \mathrm{~ms} ; 60 \mathrm{~Hz})$, the number of participants connected to the server and the ongoing data transmission.

The eye tracker must be placed directly below the computer screen. Direct and indirect light casting on the subject's face 
must be avoided because it interferes with the recording of corneal reflexes. In our experiment, the distance between the camera and the subject's eyes was $65 \mathrm{~cm}$.

For better accuracy, a calibration step must be performed. Calibration reveals possible differences between the eyes of the participant and the eye model. During calibration, the eye tracker analyzes light reflections from the subject's eyes. A bright marker will appear on the dark calibration screen, moving between 5 or 9 different positions. The participant is requested to look at each marker position. Then, a white pointof-gaze dot appears on the screen and the participant is again requested to look at each calibration point.

The following instruction was given during the calibration step: You will see white dots on the screen. You will need to look only at these dots.
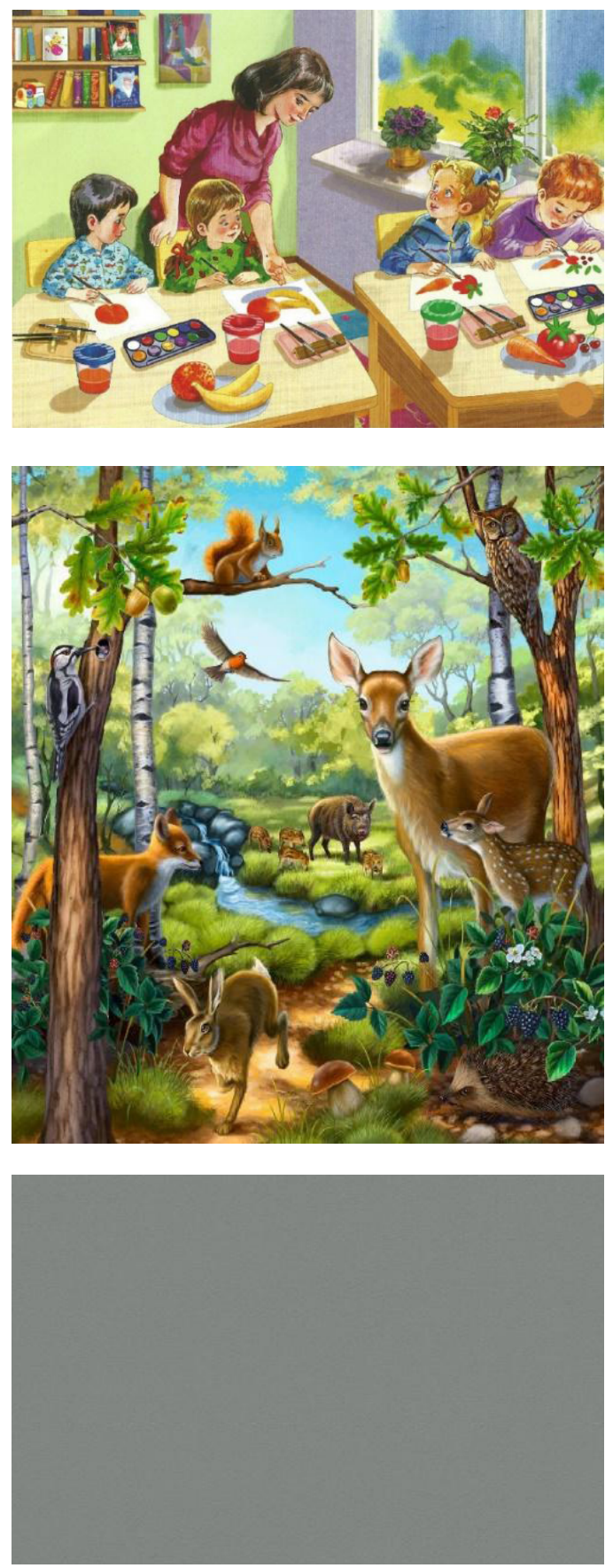

Interfering background image

Fig. 1. Example of a visual stimulus
3. During the data collection step, the following instruction was given to the participants: You will see images on the screen. You will need to look at the images very attentively without changing your posture.

Data collected during the experiment can be exported in various formats including static images, videos of gaze trajectories, heat maps and numerical ${ }^{*}$.csv data.

\section{Visual stimuli}

Visual stimuli were shortlisted by the panel of experts: teachers of primary schools for typically developing children and specialized type VIII schools for children with intellectual disabilities. Image selection criteria: image type (photos, diagrams, genre scenes, pictures of individual objects); image
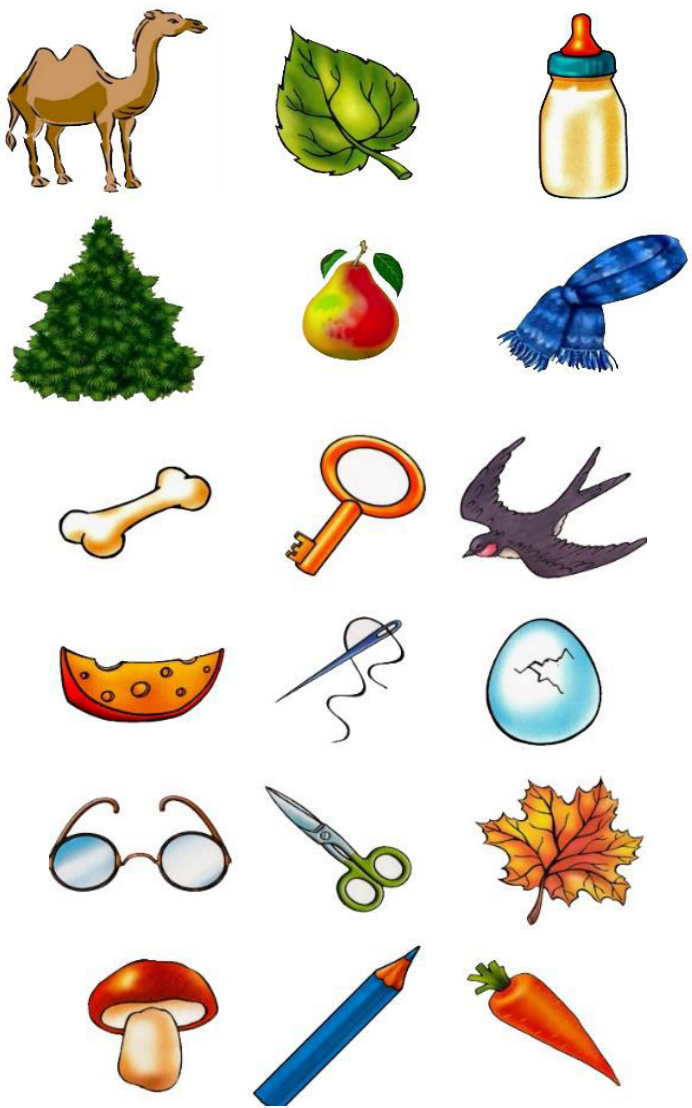

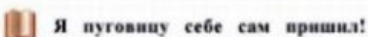

я пуговицу себ́е сам пришиз. Правда, ж ес криво пришиз, но вель \& ес сам пришил! Менх мама просит убрат со стола, ках будто бы х не ตомог своей маме, пель пугонипу а сам пришия A пчера паруг зехурнмм назначкаи " каaсce. Очень мие пужно аежуршым бит! я пель пугови.

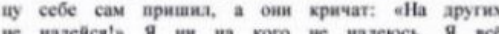

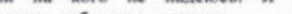
сам делам - mуговицу себе сам пришив.

$$
\text { B. Taswexum }
$$

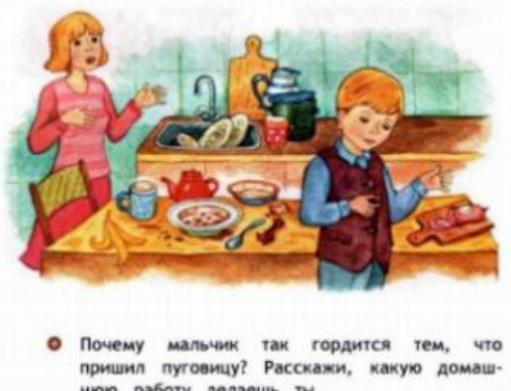
н1ю работу делаешь тu. 
A

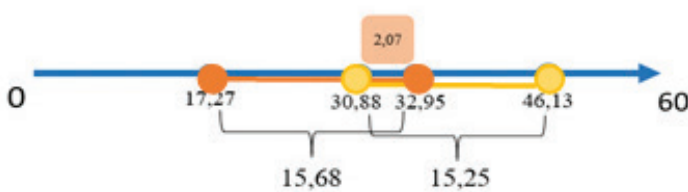

Children with mild ID

Typically developing children Total number of fixations
B

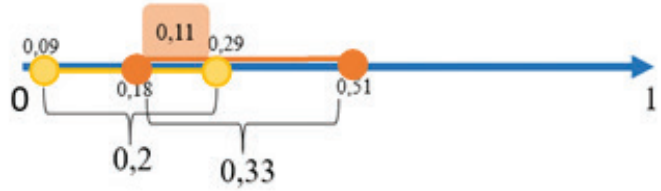

Children with mild ID

Typically developing children

Total latency

Fig. 2. The schematic representation of the overlap in the range of mean total number of fixations (A) and total latency (B) in children with ID and their typically developing peers

quality, sharpness and contrast. Criteria for final choice: bitmap images and static 2D color images (children with ID recognize basic colors but have difficulty differentiating between poorly saturated colors).

A total of 15 static color images were selected (Fig.1). Each presented image was followed by the gray background image.

The selected visual stimuli were divided into 3 groups: images depicting 6 objects (2 images showing individual objects and 3 genre scenes); images depicting 12 objects (2 images showing individual objects and 3 genre scenes); 5 images containing both pictorial and textual (task description or a legend) elements. In each experiment, images were presented in the same sequence: 1) images depicting 6 objects, 2) images depicting 12 objects, 3) images containing both pictorial and textual elements.

Resolution of the presented images: $1200 \times 1373$ for vertical images, $1920 \times 1080$ for horizontal images (consistent with the resolution of the computer screen; the aspect ratio was preserved). File format: jpg (JPEG). The children were presented with pictures from traditional school textbooks and textbooks for children with ID. Presentation time: 20 s. Background image presentation time: $3 \mathrm{~s}$. Total presentation time: $7 \mathrm{~min}$.

The following parameters of oculomotor response to $\mathrm{AOI}$ were analyzed: latency (average time to the first view); mean fixation duration (time spent looking at AOI); the average percentage of the total time spent on viewing $\mathrm{AOI}$; the total number of fixations per image (the sum of gaze fixations on each AOI per image). Each parameter was evaluated for each presented images (a picture or a combination of a picture and text).

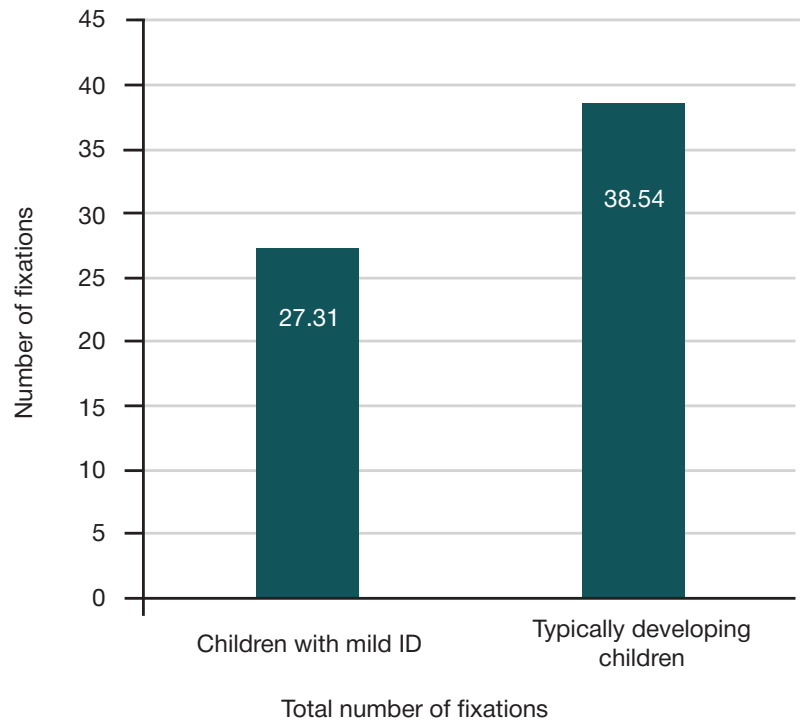

Statistical analysis was carried out using descriptive (mean values, standard deviations) and comparative statistics (nonparametric Mann-Whitney $U$ test, Wilcoxon $T$ test). Absolute values were compared between the groups.

\section{RESULTS}

The total number of fixations and total latency varied within both groups (children with ID and typically developing children (Fig. 2A, B).

The total number of fixations was significantly higher in the group of typically developing children than in their peers with mild ID ( $p=0.038)$. At the same time, the overlap in the range of mean values for this parameter between the groups was minimal. The average number of fixations was 15.68 (17.27; $32.95)$ in the main group and $15.25(30.88 ; 46.13)$ in the control group. Total latency was significantly higher $(p=0.044)$ in the group of children with mild ID than in the group of typically developing children. Average latency was $0.33(0.18 ; 0, .51)$ in the main group and $0.2(0.09 ; 0.29)$ in the control group.

These results reveal the following trend: children with mild ID fixate their gaze at fewer objects (points on the image) because they need significantly more time for fixation than typically developing children (Fig. 3).

In both groups, the number of fixations increased for pictures containing more objects (12 vs 6 objects depicted in the picture) (Table)

In both groups, the highest number of fixations was registered when children were presented with images containing 12 objects. For images containing 6 objects and

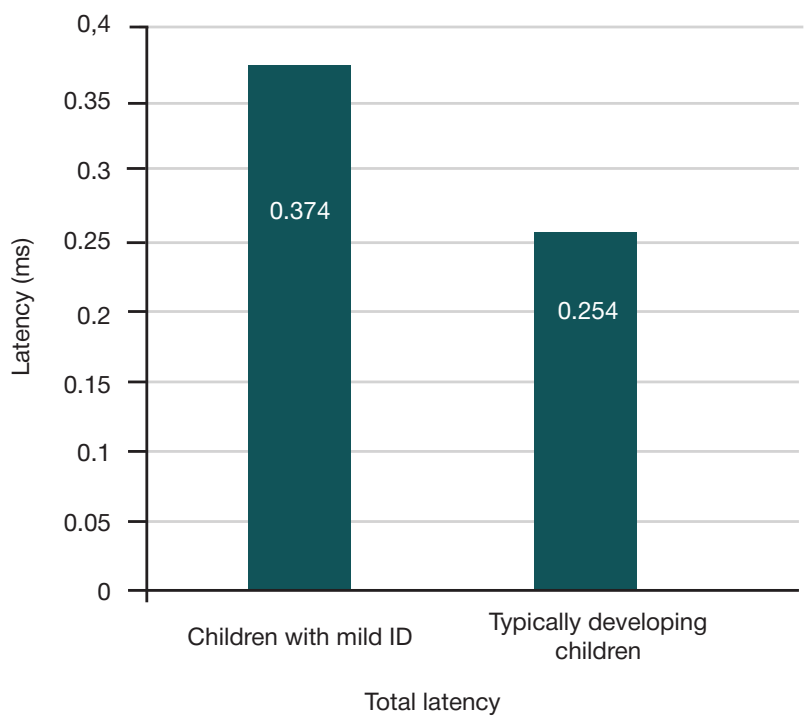

Fig. 3. A histogram showing mean values for the total number of fixations in children with mild ID and their typically developing peers 
Table. Differences in the total number of fixations between the groups presented with images containing 6 and 12 objects (Wilcoxon sign-ranked test; $p<0.05$ )

\begin{tabular}{|l|c|c|c|}
\hline & $\begin{array}{c}\text { Number of objects: } 6 \\
(\mathrm{x} \pm \sigma)\end{array}$ & $\begin{array}{c}\text { Number of objects: } 12 \\
(\mathrm{x} \pm \sigma)\end{array}$ & $p$ \\
\hline Children with mild ID & $25.15 \pm 4.49$ & $30.22 \pm 6.24$ & $0.029^{*}$ \\
\hline Typically developing children & $36.18 \pm 9.12$ & $41.39 \pm 8.42$ & $0.027^{*}$ \\
\hline
\end{tabular}

Note: * - differences are statistically significant.

images containing both pictorial and textual elements, the average number of fixations did not differ significantly between the groups (Fig. 4).

The spatial distribution of gaze fixations on the image differed significantly between typically developing children and their peers with ID.

Fig. 5 shows heat maps revealing the distribution of the number of fixations over the presented stimuli. Fig. 5A shows heat maps for a child with mild ID (age: 8 years 7 months). Fig. 5B shows heat maps for a typically developing child (age: 8 years 1 month).

In the main group, the total number of fixations on images containing 6 unrelated individual objects and on genre scenes containing 6 objects was almost the same $(p=0.75)$. Similarly, the total number of fixations on images containing 12 unrelated individual objects and on genre scenes containing 12 objects did not differ significantly in the group of children with mild ID $(p=0.73)$. Typically developing children made more fixations $(p=0.027)$ on genre scenes containing 6 objects than on images containing 6 unrelated individual objects. In this group of children, the number of fixations increased significantly ( $p=0.029)$ for genre scenes containing 12 objects, as compared with images containing 12 unrelated individual objects.

Children with mild ID ignored textual elements in mixed images and fixated on pictorial elements. Typically developing children tended to fixate their gaze predominantly on textual elements.

The fact that children with mild ID did not fixate their gaze on written text means that texts do not facilitate visual perception and are excluded from it.

Images containing 6 or 12 objects were divided into 2 groups: images of unrelated individual objects and genre scenes.

Children with mild ID tended to make fixations on the central elements of images containing unrelated individual objects (6 objects). Typically developing children made gaze fixations on the objects contained in the pictures and the space between the objects. This facilitates spatial perception, allowing the child to perceive the size of the viewed object relative to other

objects. In children with mild ID, spatial perception is impaired, which might be associated with some aspects of volitional visual perception.

When viewing genre scenes, children with mild ID tended to fixate their gaze on the heads of the depicted objects (animals and birds) and on the faces of the depicted people (teachers and children), and made only single fixations on secondary objects. In typically developing children, fixations were distributed equally between primary and secondary objects.

The ratio of gaze fixations on the peripheral elements to the fixations on the central part of the presented image (6 objects) was uniform in both groups.

When viewing images containing 12 objects, children with mild ID made more fixations on primary objects depicted in the presented images, whereas secondary objects were almost completely ignored. The maximal number of fixations was observed for the central part of the presented image vs its peripheral elements. Peripheral elements were ignored regardless of their number and importance (primary and secondary objects). In typically developing children, the number of fixations was distributed equally between the central and peripheral elements of the image.

In both groups, fixations were concentrated on human faces in cases when humans were depicted in the presented pictures. Children with mild ID tended to make fixations on adult faces, whereas their normally developing peers fixated on children's faces.

Total latency was calculated as the sum of latencies for all AOI per image. Total latency shows time from the presentation of the first stimulus to the first registered fixation. Average total latency was higher in children with mild ID than in typically developing children $(p=0.024)$, i.e. children with mild ID needed more time to fixate the gaze when viewing static images (Fig. 6A).

Regardless of the number of objects in the picture (12 or 6), children with mild ID exhibited longer latency for both central and peripheral elements than their typically developing peers. Typically developing children were faster to fixate on the peripheral elements of the presented pictures. This suggests

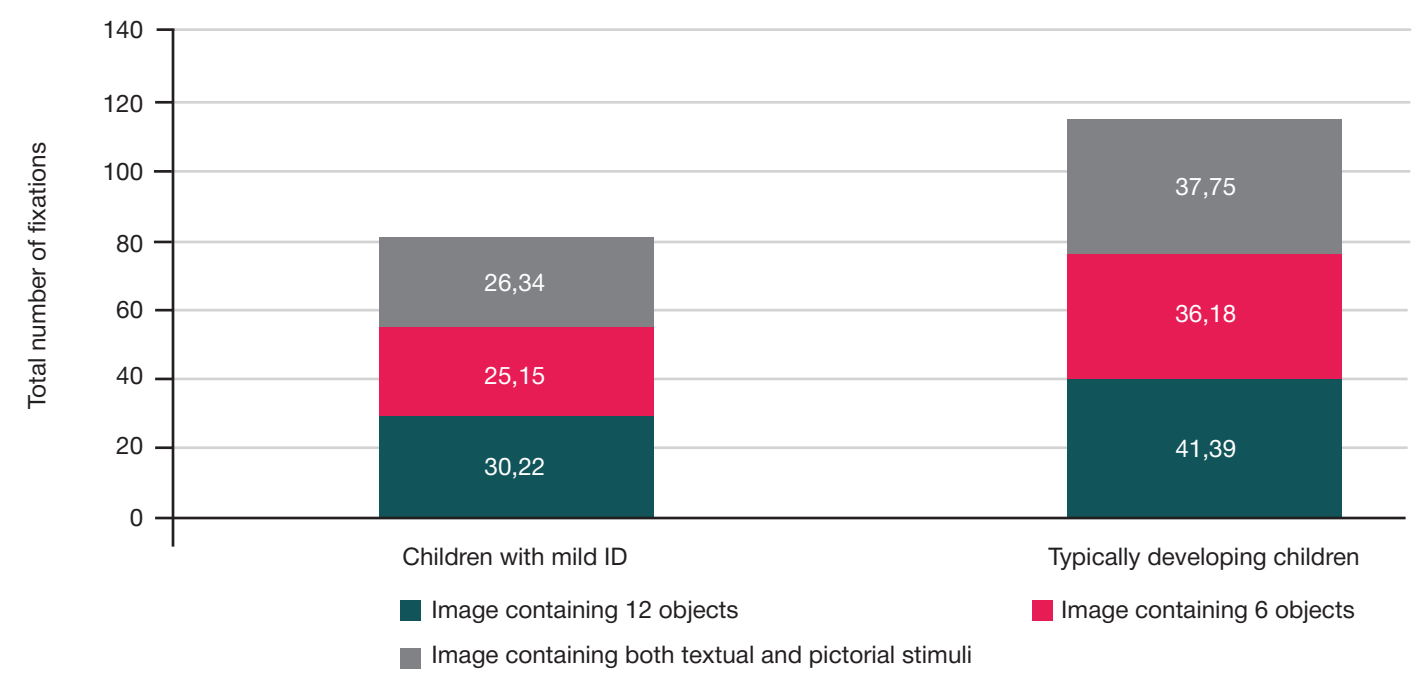

Fig. 4. Cumulative histograms showing average values for the total number of fixations in the groups presented with different types of visual stimulus 

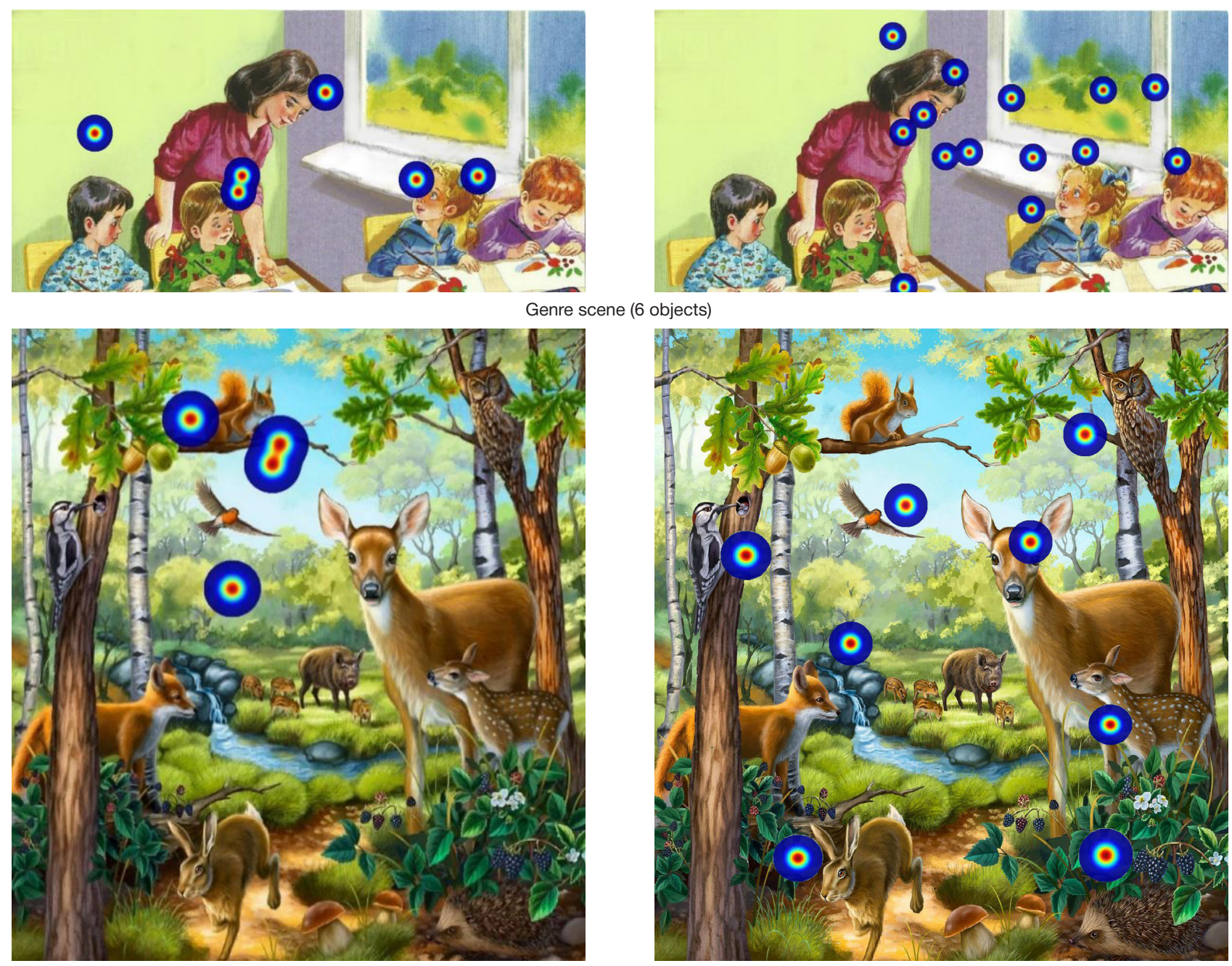

Genre scene (12 objects)
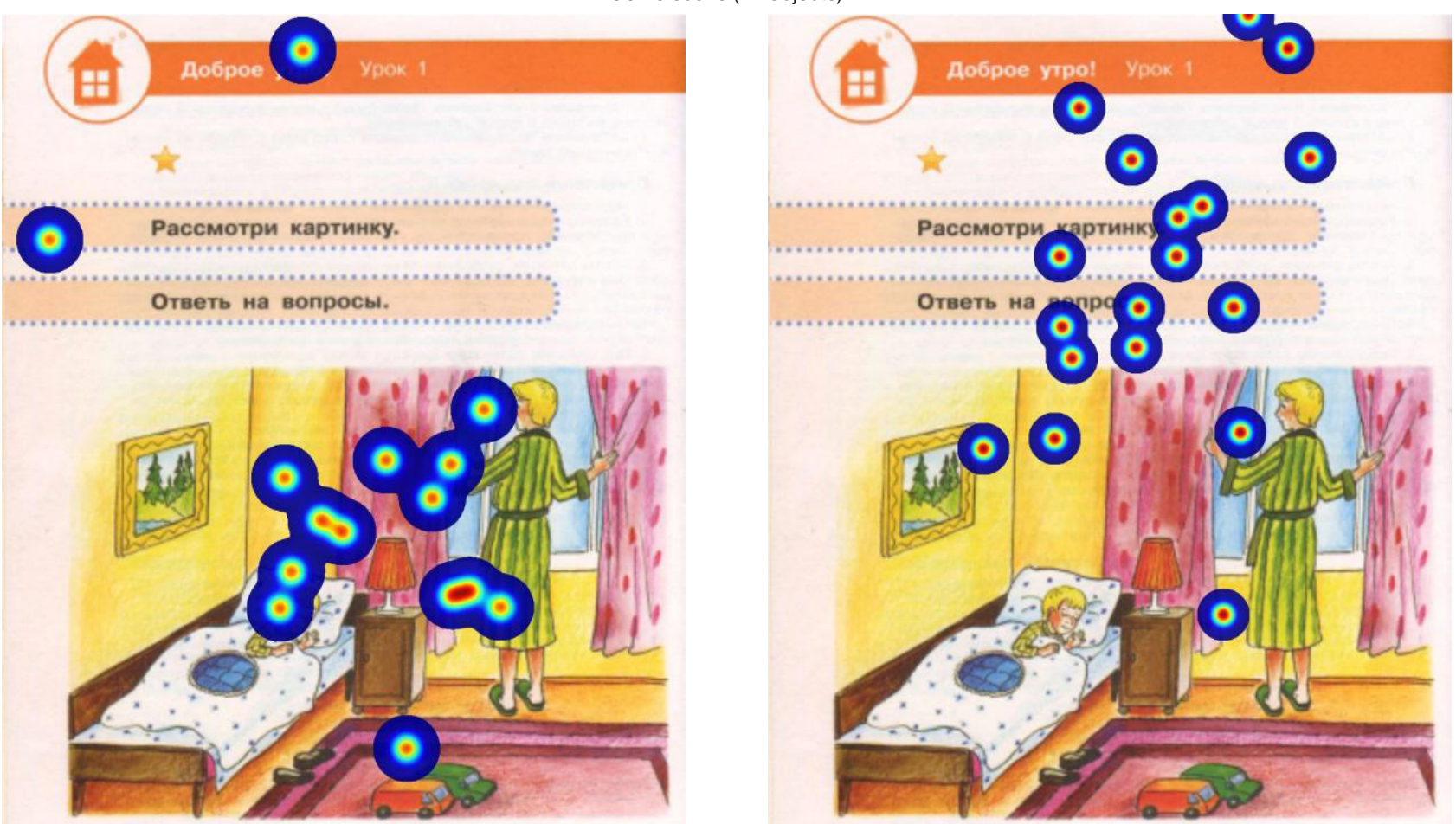

Children with mild ID

Image containing both textual and pictorial elements

Fig. 5. Heat maps of gaze fixations on the elements of mixed images in the main and control groups

Typically developing children 
A

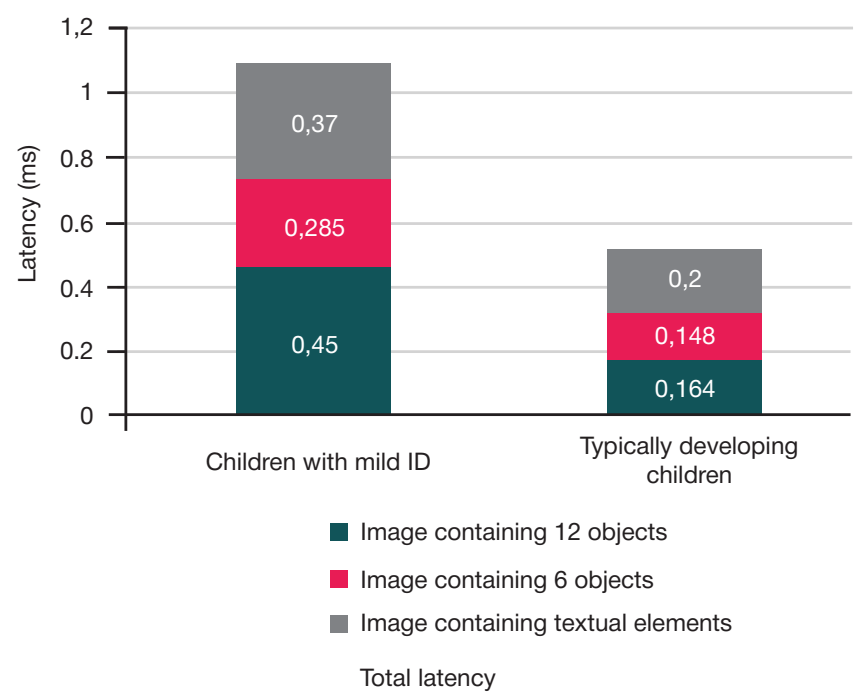

B

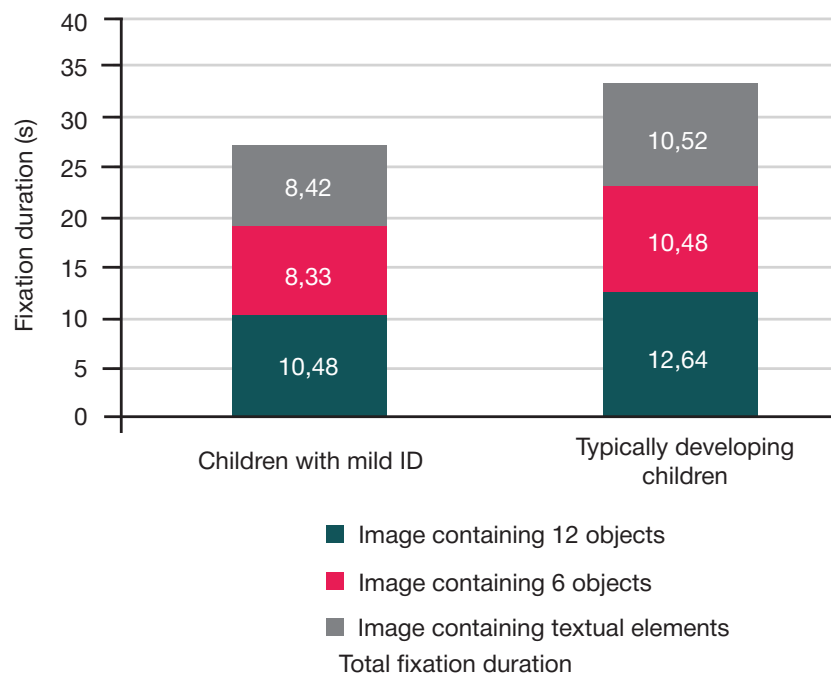

Fig. 6. Cumulative histograms showing average values for total latency (A) and fixation duration (B) in the groups presented with different types of visual stimulus

that faster fixations may be associated with faster attentional shifts in healthy children. In children with mild ID, the minimal time to a fixation on a central or peripheral element was observed for pictures containing 6 objects; so, it could be hypothesized that it is easier for such children to control their attention in the presence of fewer depicted objects.

The total duration of fixations was significantly longer in the control group $(p=0.029)$ than in the main group. The average duration of one fixation was $0.29 \pm 0.08 \mathrm{~ms}$ for typically developing children and $0.33 \pm 0.11 \mathrm{~ms}$ for children with mild ID. Thus, children with mild ID need more time to visually perceive a static image. Fewer and longer fixations made by children with mild ID are exhausting for active perception and reduce the scope of perception.

The analysis of the total duration of fixations following the presentation of different stimulus types ( 6 or 12 objects, text) suggests that the mean total duration of fixations is significantly longer $(p=0.027)$ in typically developing children than in children with mild ID (Fig. 6B). Children with mild ID spent $62.37 \pm 8.31 \%$ of the total fixation time on viewing $\mathrm{AOI}$, whereas for their typically developing peers this parameter equaled $68.42 \pm 9.14 \%$.

For children with mild ID, the total number of fixations was lower and total latency was longer.

\section{DISCUSSION}

While perceiving a static image containing multiple objects, the attention of children with mild ID is drawn to the central part of the image. This finding is consistent with the results of previous studies [10,12]. When presented with images containing fewer objects, the attention of children with mild ID is distributed more uniformly. Such children make fewer fixations when presented with images containing both textual and pictorial elements; those fixations are concentrated on pictorial elements, whereas the text is completely ignored. This is associated with the informative value of pictorial elements [7].

On the whole, typically developing children make more fixations during the experiment. The number of gaze fixations on each object $(\mathrm{AOI})$ is relatively stable regardless of the total number of objects depicted in the image (6 or 12). Fixations are uniformly distributed between the central and peripheral elements of images containing only pictorial elements. For mixed images, most fixations are concentrated on textual elements; only single fixations are registered for pictorial elements.

Children with mild ID exhibit longer latency than their typically developing peers. Children with ID need more time to perceive an image. The detected trend is consistent with the findings of other researchers who reported increased duration of gaze fixations in such children [15]. The total duration of gaze fixations in typically developing primary school students is longer than in children with mild ID. Considering that the number of fixations is greater in healthy children, the duration of a single fixation is shorter. So, the lower total number of fixations and shorter duration of fixations in children with mild ID might be explained by the fact that they need more time to perceive a static image.

\section{CONCLUSION}

The structural and dynamic characteristics of oculomotor response (the number of fixations, total fixation duration and latency) described in the study show that children with mild ID ignore textual elements on textbook pages containing a pictorial element and a task; their attention is focused on the periphery of an image if the image contains more than 6 objects.

These characteristics of oculomotor response of children with mild ID may help to optimize the form in which learning materials are presented. Attention is distributed uniformly between simultaneously presented objects if their number does not exceed 6 . If more than 6 objects are simultaneously presented on a textbook page, some of them located on the periphery escape from the field of active perception. Learning materials containing both pictorial and textual elements are ineffective because the textual elements are completely ignored. Texts and pictures should be presented in sequence. This will help to optimize the process of active perception in children with mild ID. Increased latency and increased duration of a single fixation mean that image presentation should be extended in time. 


\section{References}

1. Zdravoohranenie v Rossii. 2019: Stat. sb. / Rosstat. M., 2019; 170 s. Russian.

2. Petrova VG. Psihologija umstvenno otstalyh shkol'nikov. M.: Akademija, 2002; 160 s. Russian.

3. Luriya AR. Osnovy nejropsihologii. M.: Akademija, 2003; 384 s. Russian.

4. Berezhnaja SA. Osobennosti razvitija zritel'nogo vosprijatija u mladshih shkol'nikov s narusheniem intellektual'nogo razvitija. $\checkmark$ sbornike: Materialy nauchno-prakticheskoj konferencii; Simferopol, 16 maja 2017 g. Simferopol: Arial, 2017; s. 32-34. Russian.

5. Evlahova ZA. Osobennosti vosprijatija sjuzhetno-hudozhestvennyh kartin uchashhimisja vspomogatel'noj shkoly. Uchebnovospitatel'naja rabota v spec. shkolah. M., 1987; 205 s. Russian.

6. Zabramnaja SD. Nekotorye psihologo-pedagogicheskie poazatel razgranichenija stepenej umstvennoj otstalosti $u$ detej na nachal'nom jetape shkol'nogo obuchenija. Korrekcionnaja pedagogika. 2008; 1: 5-13. Russian.

7. Isaev DN. Umstvennaja otstalost' u detej i podrostkov. SPb.: Rech', 2007; 389 s. Russian.

8. Petrova VG. Psihologija umstvenno otstalyh shkol'nikov. M.: Akademija, 2002; 160 s. Russian.

9. Rubinshtejn SYa. Psihologija umstvenno otstalogo shkol'nika. M.:

\section{Литература}

1. Здравоохранение в России. 2019: Стат. сб. / Росстат. М., 2019; 170 c.

2. Петрова В. Г. Психология умственно отсталых школьников. М.: Академия, 2002; 160 с.

3. Лурия А. Р. Основы нейропсихологии. М.: Академия, 2003; 384 с.

4. Бережная С. А. Особенности развития зрительного восприятия у младших школьников с нарушением интеллектуального развития. В сборнике: Материалы научно-практической конференции; Симферополь, 16 мая 2017 г. Симферополь: Ариал, 2017; с. 32-34.

5. Евлахова 3. А. Особенности восприятия сюжетно художественных картин учащимися вспомогательной школы. Учебно-воспитательная работа в спец. школах. М., 1987; 205 с.

6. Забрамная С. Д. Некоторые психолого-педагогические поазатели разграничения степеней умственной отсталости у детей на начальном этапе школьного обучения. Коррекционная педагогика. 2008; 1: 5-13

7. Исаев Д. Н. Умственная отсталость у детей и подростков. СПб.: Речь, 2007; 389 с.

8. Петрова В. Г. Психология умственно отсталых школьников. М.: Академия, 2002; 160 с.

9. Рубинштейн С. Я. Психология умственно отсталого школьника.
Prosveshhenie, 1986; 192 s. Russian.

10. Solovev IM. Osobennosti poznavatel'noj dejatel'nosti uchashhihsja vspomogatel'noj shkoly. M., 2004; 378 s. Russian.

11. Tiadi A, Gérard C-L, Peyre H., Bui-Quoc E, et al. Immaturity of Visual Fixations in Dyslexic Children. Frontiers in Human Neuroscience. 2016; 10: 574-84.

12. Wang $S$, Jiang $M$, Duchesne XM, Laugeson EA, et al. Atypical Visual Saliency in Autism Spectrum Disorder Quantified through Model-Based Eye Tracking. Neuron. 2015; 88 (3): 604-16.

13. Boot $\mathrm{FH}, \mathrm{Pel} \mathrm{JJ}$, Evenhuis $\mathrm{HM}$, et al. Delayed visual orienting responses in children with developmental and/or intellectual disabilities. Journal of Intellectual Disability Research. 2012; 47: $57-58$

14. Oganov SR. Nekotorye osobennosti razvitija chitatel'skoj dejatel'nosti u detej s disleksiej 9-13 let. V sbornike: Tezisy dokladov Vserossijskoj nauchno-prakticheskoj konferencii molodyh uchenyh s mezhdunarodnym uchastiem «Fundamental'nye issledovanija v pediatrii; Sankt-Peterburg, 31 oktjabrja 2019; SPb., 2019; s. 42-43. Russian.

15. Dinevich KV, Dunaevskaja YeB. Issledovanie zritel'nogo vosprijatija tekstov raznogo vizual'nogo formata u detej s umstvennoj otstalost'ju. Kompleksnye issledovanija detstva. 2019; 2: 114120. Russian.

М.: Просвещение, 1986; 192 с.

10. Соловьев И. М. Особенности познавательной деятельности учащихся вспомогательной школы. М., 2004; 378 с.

11. Tiadi A, Gérard C-L, Peyre H., Bui-Quoc E, et al. Immaturity of Visual Fixations in Dyslexic Children. Frontiers in Human Neuroscience. 2016; 10: 574-84.

12. Wang S, Jiang M, Duchesne XM, Laugeson EA, et al. Atypical Visual Saliency in Autism Spectrum Disorder Quantified through Model-Based Eye Tracking. Neuron. 2015; 88 (3): 604-16.

13. Boot FH, Pel JJ, Evenhuis HM, et al. Delayed visual orienting responses in children with developmental and/or intellectual disabilities. Journal of Intellectual Disability Research. 2012; 47: 57-58.

14. Оганов С. Р. Некоторые особенности развития читательской деятельности у детей с дислексией 9-13 лет. В сборнике: Тезисы докладов Всероссийской научно-практической конференции молодых ученых с международным участием «Фундаментальные исследования в педиатрии; СанктПетербург, 31 октября 2019; СПб., 2019; с. 42-43.

15. Диневич К. В., Дунаевская Э. Б. Исследование зрительного восприятия текстов разного визуального формата у детей с умственной отсталостью. Комплексные исследования детства. 2019; 2: 114-120. 